\title{
Dasatinib Anhydrous
}

National Cancer Institute

\section{Source}

National Cancer Institute. Dasatinib Anhydrous. NCI Thesaurus. Code C74556.

An orally bioavailable synthetic small molecule-inhibitor of SRC-family protein-tyrosine kinases. Dasatinib binds to and inhibits the growth-promoting activities of these kinases. Apparently because of its less string ent binding affinity for the BCR-ABL kinase, dasatinib has been shown to overcome the resistance to imatinib of chronic myeloid leukemia $(C M L)$ cells harboring BCR-ABL kinase domain point mutations. SRC-family proteintyrosine kinases interact with variety of cell-surface receptors and participate in intracellular signal transduction pathways; tumorigenic forms can occur through altered regulation or expression of the endogenous protein and by way of virally-encoded kinase genes. 